\title{
Enzyme Unit per Milliliter
}

National Cancer Institute

\section{Source}

National Cancer Institute. Enzyme Unit per Milliliter. NCI Thesaurus. Code C67367.

Unit of catalytic activity concentration defined as activity equal to one enzyme unit per one milliliter of system volume. 